\title{
Same-Sex Privacy and the Limits of Antidiscrimination Law
}

\author{
Amy Kapczynski
}

Whereas a "customer preference" will not justify a job qualification based on sex, an invasion of privacy will. ${ }^{1}$

$[\mathrm{M}]$ ores as to being viewed naked by members of the opposite sex under certain circumstances are bound to change as women become further integrated into the occupational and professional world. The traditional rule that only male guards may view male inmates under these conditions may derive from just the type of stereotypical value system condemned by Title VII. ${ }^{2}$

\section{INTRODUCTION}

Title VII of the 1964 Civil Rights Act, ${ }^{3}$ as it has been interpreted by the courts, is an uncompromising statute. It bars adverse employment actions taken on the basis of race, color, religion, sex, and national origin, with only one exception: in cases where an employer can demonstrate that sex, religion, or national origin is a "bona fide occupational qualification [BFOQ] reasonably necessary to the normal operation of that particular

1. Backus v. Baptist Med. Ctr., 510 F. Supp. 1191, 1194 (E.D. Ark. 1981), vacated as moot, 671 F.2d 1100 (8th Cir. 1982).

2. Gunther v. lowa State Men's Reformatory, 462 F. Supp. 952, 956 n.4 (N.D. Iowa 1979) (citation omitted), aff'd, 612 F.2d 1079 (8th Cir. 1980).

3. The statute reads, in relevant part:

It shall be an unlawful employment practice for an employer-

(1) to fail or refuse to hire or to discharge any individual, or otherwise to discriminate against any individual with respect to his compensation, terms, conditions, or privileges of employment, because of such individual's race, color, religion, sex, or national origin; or

(2) to limit, segregate, or classify his employees or applicants for employment in any way which would deprive or tend to deprive any individual of employment opportunities or otherwise adversely affect his status as an employee, because of such individual's race, color, religion, sex, or national origin.

42 U.S.C. $\S 2000 \mathrm{e}-2(\mathrm{a})(2000)$. 
business or enterprise."4 Much of Title VII's impact, of course, depends upon the scope given to this exception, and, in particular, upon whether employers are allowed to claim inconvenience, cost, or customer preference as legitimate components of the BFOQ analysis. Because a broad exception would swallow the rule, the Supreme Court has held that the BFOQ provision was "meant to be an extremely narrow exception to the general prohibition of discrimination"s and established a stringent test for its application. An employer seeking a sex-based BFOQ must have a "'factual basis" to believe that "“all or substantially all women [or men] would be unable to perform safely and efficiently the duties of the job involved,", or, alternatively, demonstrate that the qualification in question relates to "the 'essence,' or to the 'central mission of the employer's business.",

Courts have also strongly rejected attempts to define the "essence of a business" in ways that allow sex discrimination in through the back door of customer preference. The logic is the same as that justifying a narrow BFOQ: As one court put it, "[I]t would be totally anomalous if we were to allow the preferences and prejudices of the customers to determine whether the sex discrimination was valid. Indeed, it was, to a large extent, these very prejudices the Act was meant to overcome." ${ }^{\prime 8}$ Thus, courts have refused to allow the preferences of airline customers to justify rejection of men for flight attendant positions, ${ }^{9}$ or the biases of customers or associates in other countries to justify refusal to promote women to positions directing international operations. ${ }^{10}$

To date, only a few kinds of sex-based BFOQs have been approved. The Supreme Court has authorized only one: In 1977, the Court granted a sex-based BFOQ to an Alabama maximum security prison, allowing it to

4. 42 U.S.C. $\$ 2000 \mathrm{e}-2(\mathrm{e})(1)$. The BFOQ provision of Title VII reads:

[I]t shall not be an unlawful employment practice for an employer to hire and employ employees ... on the basis of his religion, sex, or national origin in those certain instances where religion, sex, or national origin is a bona fide occupational qualification reasonably necessary to the normal operation of that particular business or Id. enterprise.

5. Dothard v. Rawlinson, 433 U.S. 321 , 334 (1977); see also UAW v. Johnson Controls, Inc., 499 U.S. 187, 201 (1991) ("The BFOQ defense is written narrowly, and this Court has read it narrowly. ... Our emphasis on the restrictive scope of the BFOQ defense is grounded on both the language and the legislative history of $\S 703$." (citations omitted)).

6. Dothard, 433 U.S. at 333 (quoting Weeks v. S. Bell Tel. \& Tel. Co., 408 F.2d 228, 235 (5th Cir. 1969))

7. Johnson Controls, 499 U.S. at 203 (citations omitted).

8. Diaz v. Pan Am. World Airways, Inc., 442 F.2d 385, 389 (5th Cir. 1971); see also 1 LEX K. LARSON, EMPLOYMENT DISCRIMINATION $\$ 11.02$, at 11-6 (2d ed. 2002) ("[C]ourts have uniformly rejected asserted BFOQs that are based on customer or client preferences, usually citing the fact that these biases are exactly the type of discrimination that Title VII was designed to eliminate.").

9. E.g., Diaz, 442 F.2d at 388; Wilson v. Southwest Airlines Co., 517 F. Supp. 292 (N.D. Tex. 1981).

10. Fernandez v. Wynn Oil Co., 653 F.2d 1273, 1276-77 (9th Cir. 1981). 
exclude women from certain positions to ensure the safe administration of the prison. ${ }^{11}$ Lower courts and commentators have suggested that there may be many other kinds of BFOQs, including an "authenticity" BFOQ, which, for example, allows employers to hire only women for special undercover operations or theater productions, ${ }^{12}$ a "role model" BFOQ, ${ }^{13}$ and a BFOQ for rehabilitation purposes. ${ }^{14}$

Sex-based BFOQs are of interest not only because they authorize acts that would otherwise be considered discriminatory, but because they are a key location where sexual difference is symbolized in the law. If the law "interpellates" us, or recruits us into identities and ideologies that it names for and as us, ${ }^{15}$ then sex-based BFOQs offer us a unique vantage point from which to understand how we are created as legal subjects of sex. This Note examines one sex-based BFOQ, which eclipses all others in terms of its legitimacy, persistence, and breadth: the same-sex privacy BFOQ, which allows employers explicitly to exclude men or women from certain positions or employment opportunities to protect the privacy interests of customers of the opposite sex. It excuses a wide variety of overtly sexbased employment actions, from the seemingly trivial-the refusal to assign women to clean men's bathrooms ${ }^{16}$ - to the relatively extreme-the refusal to hire qualified men to fill any of the nursing positions in labor and delivery rooms. ${ }^{17}$

In 1991, the Supreme Court explicitly suggested that same-sex privacy could be the basis for a BFOQ, ${ }^{18}$ and both before and after that, lower courts have granted same-sex privacy BFOQs in a variety of contexts

11. Dothard, 433 U.S. at 334-35.

12. See 29 C.F.R. § 1604.2(a)(1)-(2) (2001) (indicating that BFOQs will not be granted on the basis of "the preferences of coworkers, the employer, clients or customers except ... [w] $w e r e$ it is necessary for the purpose of authenticity or genuineness"); 3 LARSON, supra note 8 , $\$ 43.02[2]$, at $43-5$.

13. See Chambers v. Omaha Girls Club, Inc., 834 F.2d 697, 705 (8th Cir. 1987).

14. See Torres v. Wis. Dep't of Health \& Soc. Servs., 859 F.2d 1523, 1529-32 (7th Cir. 1988).

15. "Interpellation" is the term Louis Althusser gave to the law's power to call subjects into being. Althusser's privileged metaphor for interpellation is the moment when an individual in the street, hailed by a policeman who shouts, "Hey, you there!", turns to face the officer, becoming the "you" that was called. See Louis Althusser, Ideology and Ideological State Apparatuses (Notes Toward an Investigation), in LENIN AND PHILOSOPHY AND OTHER ESSAYS 127, 170-77 (Ben Brewster trans., 1971).

16. Norwood v. Dale Maint. Sys., Inc., 590 F. Supp. 1410 (N.D. Ill. 1984); Brooks v. ACF Indus., Inc., 537 F. Supp. 1122 (S.D. W. Va. 1982).

17. EEOC v. Mercy Health Ctr., 29 Fair Empl. Prac. Cas. (BNA) 159 (W.D. Okla. 1982); Backus v. Baptist Med. Ctr., 510 F. Supp. 1191 (E.D. Ark. 1981), vacated as moot, 671 F.2d 1100 (8th Cir. 1982).

18. See UAW v. Johnson Controls, Inc., 499 U.S. 187, 206 n.4 (1991) (noting that "[n]othing in our discussion of the 'essence of business test,' however, suggests that sex could not constitute a BFOQ when privacy interests are implicated," and characterizing Backus as holding that the "essence of obstetric nurse's business is to provide sensitive care for patient's intimate and private concerns" (citing Backus, 510 F. Supp. 1191)). 
including labor and delivery rooms, ${ }^{19}$ mental hospitals, ${ }^{20}$ youth centers, ${ }^{21}$ washrooms, ${ }^{22}$ and nursing homes. ${ }^{23}$ Some courts have also granted samesex privacy BFOQs in prisons, ${ }^{24}$ although many others have rejected them. ${ }^{25}$ Recently, employers have begun claiming-if not obtainingBFOQ defenses in a variety of new settings, including weight-loss centers, ${ }^{26}$ health clubs, ${ }^{27}$ and spas. ${ }^{28}$

This Note addresses same-sex privacy cases because in them Title VII's strong command to remake the world in favor of employment equity and at the expense of discriminatory customer preferences meets its limit. These cases are striking not only because they appear to be the strongest category of sex-based exceptions to Title VII, but also because they are deeply untheorized and impossible to square with Title VII's much-vaunted rejection of customer preference. As Robert Post has pointed out, same-sex privacy cases illustrate how "Title VII does not simply displace gender practices, but rather interacts with them in a selective manner," and they also "force[] us to ask which gender practices are to be reshaped by Title VII, in what contexts, and in what ways. $" 29$

19. Mercy Health Ctr., 29 Fair Empl. Prac. Cas. (BNA) at 159; Backus, 510 F. Supp. 1191.

20. Healey v. Southwood Psychiatric Hosp., 78 F.3d 128, 134 (3d Cir. 1996) (holding that sex is a BFOQ in a youth psychiatric facility); Jennings v. N.Y. State Office of Mental Health, 786 F. Supp. 376 (S.D.N.Y 1992), aff'd, 977 F.2d 731 (2d Cir. 1992). 1973).

21. City of Philadelphia v. Pa. Human Relations Comm'n, 300 A.2d 97 (Pa. Commw. Ct

22. Brooks v. ACF Indus., 537 F. Supp. 1122 (S.D. W. Va. 1982).

23. Fesel v. Masonic Home of Del., Inc., 447 F. Supp. 1346 (D. Del. 1978), aff'd mem., 591 F.2d 1334 (3rd Cir. 1979).

24. See, e.g., Hudson v. Goodlander, 494 F. Supp. 890, 893 (D. Md. 1980) (holding that the interests of female guards in equal employment opportunities were not compelling enough to override male inmates' privacy rights in situations where inmates were regularly viewed naked).

25. See, e.g., Forts v. Ward, 621 F.2d 1210, 1217 (2d Cir. 1980) (denying a sex-based BFOQ for prison guards assigned to night shifts in women's prison dormitories because measures to accommodate inmate privacy concerns were available); Griffin v. Mich. Dep't of Corr., 654 F. Supp. 690, 702 (E.D. Mich. 1982) (rejecting a BFOQ because the viewing of unclothed inmates was not "intrinsically more odious" when the surveillance was cross-sex); Harden v. Dayton Human Rehab. Ctr., 520 F. Supp. 769, 781 (S.D. Ohio 1981) (rejecting a female-sex BFOQ for a prison guard position because the employer had not demonstrated that it could not rearrange job duties so as to avoid the conflict between privacy and equal employment), aff'd, $779 \mathrm{~F} .2 \mathrm{~d} 50$ (6th Cir. 1985); Gunther v. Iowa State Men's Reformatory, 462 F. Supp. 952, 957 (N.D. Iowa 1979) (refusing to grant a male-sex BFOQ for corrections officers in a men's penal institution because institutional adjustments could be made to respect inmate privacy without hindering the operation of the facility), aff'd, 612 F.2d 1079 (8th Cir. 1980).

26. EEOC v. HI 40 Corp., 953 F. Supp. 301 (W.D. Mo. 1996).

27. Foster v. Back Bay Spas, Inc., No. 96-7060, 1997 Mass. Super. LEXIS 194 (Mass. Super. Ct. Sept. 29, 1997). For feminist defenses of women-only health clubs that refuse to hire men, sec Miriam A. Cherry, Exercising the Right to Public Accommodations: The Debate over Single-Sex Health Clubs, 52 ME. L. REv. 97 (2000); and Michael R. Evans, The Case for All-Female Health Clubs: Creating a Compensatory Purpose Exception to State Public Accommodation Laws, 11 YALE J.L. \& FEMINISM 307 (1999).

28. Olsen v. Marriott Int'l, Inc., 75 F. Supp. 2d 1052 (D. Ariz. 1999).

29. See Robert Post, Prejudicial Appearances: The Logic of American Antidiscrimination Law, 88 CAL. L. REV. 1, $26(2000)$ 
But how are we to know or decide which gender practices Title VII should challenge? This Note derives two teachings from same-sex privacy cases: first, that we must consider the symbolically as well as materially discriminatory effects of gender norms to decide which norms to challenge, and, second, that our inquiry must not end there. These cases make clear that costs attach not only to gender norms but also to their transformation. At times, courts will need to mediate between the discriminatory effects of a norm and the discriminatory effects of the attempt to change it. In such cases, I contend, effective resolution of this dilemma will usually not reside in sex segregation, but rather in non-sex-specific measures to alleviate the kinds of risks and costs we too quickly identify with sex itself.

Part II demonstrates that the same-sex privacy doctrine fails to meet the stringent requirements established for BFOQs. There is no evidence in most same-sex privacy cases that all or substantially all members of one sex cannot perform the essential functions of the job in question. In fact, samesex privacy BFOQs are simply concessions to customer preference, and they undermine employment equity in just the way that courts usually have held Title VII opposes.

Courts in search of a principle that distinguishes the grounds of this BFOQ from forbidden customer preference typically turn to the law of privacy, but as Part III shows, this turn is too quickly made. Upon examination, it becomes clear that there are in many cases no relevant privacy rights at stake. Even in cases where there are privacy rights at stake, there is no logical reason to collapse privacy rights with sex and status as same-sex privacy doctrine does.

If same-sex privacy cases are really about customer preferences, and cannot be defended via recourse to legally recognized privacy rights, how can they be explained? Part IV contends that there are two interrelated justifications at work in these cases. First, courts insist that same-sex privacy norms are so deeply held and so fundamental to our sense of identity that they are legitimately cast beyond the reach of antidiscrimination law. Second, courts imply that same-sex privacy norms should be respected because they are necessary for the physical and psychological protection of individuals.

Part $\mathrm{V}$ asks whether either line of reasoning adequately justifies the exclusion of same-sex privacy norms from the set of gender norms that Title VII contests. It contends that they do not and that same-sex privacy doctrine is both materially and symbolically discriminatory. The claim of material discrimination is straightforward: The same-sex privacy BFOQ disadvantages women in the labor market because it facilitates the steering of women into low-status jobs. The notion of symbolic discrimination is less familiar, and one that I attempt to define against the background of these cases. Same-sex privacy cases, I argue, reinforce a symbolic order of 
gender that has a discriminatory effect upon women, because, for example, it casts them as constitutively vulnerable to sexualized attack, and as essentially and necessarily modest in a way that resonates with tendencies to propertize women and deny them sexual agency. These and the other symbolically discriminatory effects of the doctrine should concern us, and Title VII. These cases, however, suggest that it is not enough to ask which norms to challenge: We must also consider where and when to challenge them. Where changing gender norms will occasion costs such as the fear or risk of sexual abuse, we should take these costs seriously. Sex segregation, however, will rarely be the most effective way of avoiding these costs. Because of this, I conclude, same-sex privacy BFOQs should rarely, if ever, be judged legitimate.

\section{The Bona Fides of SAME-SeX PRIVACY}

In Dothard v. Rawlinson, the Supreme Court set a high bar for BFOQ exceptions, offering two tests for the granting of the defense. A BFOQ can be justified if " the essence of the business operation would be undermined by not hiring members of one sex exclusively, ${ }^{, 30}$ or if employers have "'reasonable cause to believe, that is, a factual basis for believing, that all or substantially all women would be unable to perform safely and efficiently the duties of the job involved.",31

Courts read these requirements narrowly and strictly. Focusing on the wording of the statute, the Supreme Court has insisted that "the most telling term is 'occupational'; this indicates that these objective, verifiable requirements must concern job-related skills and aptitudes." ${ }^{32}$ In $U A W v$. Johnson Controls, Inc., the Court demonstrated the rigor of this requirement by refusing to define fetal safety as part of the essence of the business of battery making, noting, "No one can disregard the possibility of injury to future children; the BFOQ, however, is not so broad that it transforms this deep social concern into an essential aspect of battery making., 33

The Johnson Controls Court also circumscribed the ability of employers to claim cost as a factor supporting the need for a BFOQ ${ }^{34}$ As a

30. Dothard v. Rawlinson, 433 U.S. 321, 333 (1977) (quoting Diaz v. Pan Am. World Airways, 442 F.2d 385, 388 (5th Cir. 1971)).

31. Id. (quoting Weeks v. S. Bell Tel. \& Tel. Co., 408 F.2d 228, 235 (5th Cir. 1969)).

32. UAW y. Johnson Controls, Inc., 499 U.S. 187, 201 (1991).

33. Id. at 203-04.

34. Dismissing Justice White's concurrence, the majority noted that " $[\mathrm{b}] \mathrm{y}$ limiting his discussion to cost and safety concerns and rejecting the 'essence of the business' test that our case law has established, [Justice White] seeks to expand what is now the narrow BFOQ defense." Id. at 203. Additionally, by requiring that employers bear the risk of tort liability in this case-one that the majority characterized as "remote," id. at 208 , but that the concurrence considered much 
rule, courts do not consider cost a legitimate justification for evading the requirements of antidiscrimination law. ${ }^{35}$ The rejection of cost as a justification is essential to Title VII's power, since "[t]o allow this physical limitation to become an independent ground for continued discrimination because of the expense of adapting to the 'new era' would be nothing less than honoring a self-perpetuating vehicle of discrimination.,36

For the same reason, discriminatory customer preferences are also unacceptable grounds for a BFOQ, according to both EEOC regulations ${ }^{37}$ and the courts. ${ }^{38}$ For example, in Diaz v. Pan American World Airways, Inc., the Fifth Circuit sharply refused a BFOQ based upon sex to an airline that wanted to hire only female flight attendants, holding that the proffered justifications - the preferences and "special psychological needs of [airline] passengers"-were not part of the "primary function" of an airline. ${ }^{39}$

If costs and customer preference are not legitimate factors in the BFOQ analysis, why do courts consider same-sex privacy a legitimate basis for a BFOQ? Many courts have struggled with this question; more have avoided it. In one of the earliest and most oft-cited same-sex privacy cases, Fesel $v$. Masonic Home of Delaware, Inc., a Delaware district court considered whether to grant a same-sex BFOQ to a residential retirement home in order to allow it to hire only female nurse's aides. ${ }^{40}$ The court followed Dothard in declaring that the employer must prove a factual basis for believing that hiring any male nurse's aides would "directly undermine the essence of the job involved or the employer's business," and that there was no way to

more likely, id. at 212-14 (White, J., concurring) the Court minimized the role of cost concerns in the BFOQ context.

35. 1 LARSON, supra note 8, $\$ 11.02[4]$, at 11-12. Larson notes:

The added expense entailed in complying with Title VII is generally not a valid basis for a bona fide occupational qualification. Thus, the cost of hiring members of two sexes instead of one, in the form of constructing separate restrooms, berths, showers, and the like, or in the form of increased costs of insurance or pension benefits, is not a basis for a bona fide occupational qualification exception unless the expense in the Id. circumstances would be clearly unreasonable.

36. Id. § 11.02[4], at 11-15.

37. 29 C.F.R. $\$ 1604.2(a)(1)-(2)(2001)$.

38. See Diaz y. Pan Am. World Airways, Inc., 442 F.2d 385, 387-88 (5th Cir. 1971). Similarly, courts have rejected sex-based discrimination in favor of male waiters in "high-class" restaurants. Levendos v. Stem Entm't, Inc., 723 F. Supp. 1104, 1107 (W.D. Pa. 1989), rev'd on other grounds, 909 F.2d 747 (3d Cir. 1990); see also 3 LARSON, supra note 8, § 43.03[2], at 4337 to -38 . Commentators note that the black letter rule against customer preference does not extend to cases where "the distinctiveness of the product itself would be lost" (as in, for example, a topless bar). 3 LARSON, supra note $8, \S 43.03[4]$, at 43-49; see also Wilson v. Southwest Airlines Co., 517 F. Supp. 292, 301 (N.D. Tex. 1981) (" $[I] n$ jobs where sex or vicarious sexual recreation is the primary service provided, e.g. a social escort or topless dancer, the job automatically calls for one sex exclusively; the employee's sex and the service provided are inseparable.").

39. Diaz, 442 F.2d at $387-88$.

40. 447 F. Supp. 1346 (D. Del. 1978), aff'd mem., 591 F.2d 1334 (3d Cir. 1979). 
reassign job duties so as to avoid the privacy/equality conflict. ${ }^{41}$ To prove this factual basis, the court then promptly turned to evidence of customer preference, noting:

The administrators of the Home believed that the employment of a male nurse's aide at the Home would have undermined the essence of the Home's operation because female guests would not consent to having their personal needs attended to by a male, and because some of the female guests would leave the Home if there were male nurse's aides. ${ }^{42}$

In the same-sex privacy context, not only customer preference but also potential cost is considered an important aspect of the employer's consideration, in direct contradiction to the rest of BFOQ doctrine. In Fesel, the court held that it was simply "not feasible" for the nursing home in question to hire an additional staff person-presumably because of the cost. ${ }^{43}$ Similarly, in Norwood v. Dale Maintenance System, Inc., an Illinois district court allowed a BFOQ for sex-based assignments for washroom janitors, after explicitly considering the cost of alternative staffing arrangements and changing the locks on bathroom doors. ${ }^{44}$ That court even went so far as to make customer preference itself part of the test for a samesex privacy BFOQ. ${ }^{45}$

The problem is the same one that attends all concessions to customer preference: They exactly reproduce the prejudices that generate gendered stratification and hierarchy in the work force in the first place. Note for a moment the partiality of a privacy regime constructed on employers' presumptions about customer preferences. The employers in Fesel, as in other nursing care cases, refused to hire male nurses to care for female patients, but they regularly allowed female nurses to provide intimate care for male patients. ${ }^{46}$ Similarly, the same hospitals that refused to allow male
41. Id. at 1351 .
42. Id. at 1352 .
43. Id. at 1353 .
44. Norwood v. Dale Maint. Sys., Inc., 590 F. Supp. 1410, 1418 (N.D. Ill. 1984)
45. The court stated:
A defendant in privacy rights cases may satisfy its burden of proving a factual basis for a sex-based hiring policy by showing that the clients or guests of a particular business would not consent to service by a member of the opposite sex, and that the clients or guests would stop patronizing the business if members of the opposite sex were allowed to perform the service.

Id. at 1416.

46. Fesel, 447 F. Supp. at 1353 n.5. The same was true of the defendant hospital in Backus v. Baptist Medical Center, as Deborah Calloway notes:

[A]lthough the opinion never discusses the duties of female nurses outside the maternity ward, female nurses at Baptist do provide intimate care to male patients. The hospital does not bar female nurses from positions requiring that they provide intimate care to male patients. Female nurses bathe male patients, help them use the toilet, 
nurses to provide intimate care for female patients regularly allowed male doctors to provide such care for female patients. ${ }^{47}$ As Deborah Calloway has pointed out, the same-sex privacy doctrine as currently constructed reinforces sex segregation in some of the most stubbornly segregated sectors of the U.S. labor market. Because it relies upon received wisdom about privacy, the current approach "expressly maintains the status quo. Intimate contact ... is acceptable when . . . females fill their traditional role as nurses and males fill their traditional role as doctors, police officers and prison guards. Privacy interests are asserted and prevail when men or women attempt to break into the traditionally segregated professions.",48

As Calloway intimates, sexual privacy BFOQs are sought and granted in ways that reinforce the hierarchical segregation of the job market. Consider: If women cannot be assigned male nurses for intimate care but men can be assigned female nurses, hospitals and courts are defending rules that help ensure that women will continue to dominate the nursing field. Consider too the compound effect that the exception for male doctors has: Men are steered into highly paid, high-prestige doctor positions, while women are expected to staff lower-paid nursing positions. The only plausible explanation for this professionalism bias is gendered job stereotyping. ${ }^{49}$

administer shots and give them enemas. As a matter of practice rather than policy, male orderlies and male nurses insert catheters in male patients and shave their genital hair in preparation for surgery.

Deborah Calloway, Equal Employment and Third Party Privacy Interests: An Analytical Framework for Reconciling Competing Rights, 54 FORDHAM L. REV. 327, 355 (1985).

47. In EEOC v. Mercy Health Center, both of the doctors who "perform[ed]" most of the deliveries in the ward were male. 29 Fair Empl. Prac. Cas. (BNA) 159, 161 (W.D. Okla. 1982). At Baptist Medical Center, nine of the eleven ob-gyn doctors were men. Backus v. Baptist Med. Ctr., 510 F. Supp. 1191, 1192 (E.D. Ark. 1981), vacated as moot, 671 F.2d 1100 (8th Cir. 1982). In Backus, the court dismissed this issue by accepting at face value Baptist Medical's policy of allowing patients to choose their doctors but not their nurses:

The fact that the plaintiff is a health care professional does not eliminate the fact that he is an unselected individual who is intruding on the obstetrical patient's right to privacy. The male nurse's situation is not analogous to that of the male doctor who has been selected by the patient.

Id. at 1195.

48. Calloway, supra note 46 , at $329-30$. I take a slightly different view of the prison cases. Courts frequently value employment equity over privacy in the prison context, which sometimes has the effect of facilitating women's entry into the traditionally male domain of corrections. See infra note 52.

49. Calloway, supra note 46 , at 361-62. Interestingly enough, this gendered regime is a fairly recent one. Until the late nineteenth century, and the famous Florence Nightingale, nursing was male work. After Nightingale, hospital "dirty work" became "women's work." See Henry Etzkowitz, The Male Sister: Sexual Separation of Labor in Society, 33 J. MARRIAGE \& FAM. 431, 432 (1971), quoted in Calloway, supra note 46, at $360 \mathrm{n} .161$. These norms may be slowly changing, particularly regarding doctors. Men still make up about sixty-four percent of practicing ob-gyn doctors, but women are now the majority of ob-gyn doctors-in-training. See Tamar Lewin, Women's Health Is No Longer a Man's World, N.Y. TIMES, Feb. 7, 2001, at Al. Last year, more than seventy percent of the nation's ob-gyn residencies were filled by women. Id. Male ob-gyn doctors have begun to complain that they feel discriminated against because women prefer female 
As they authorize the exclusion of men from "women's" professions, courts have also authorized the exclusion of women from typically male professions such as janitorial work ${ }^{50}$ and youth supervision in juvenile correction facilities. ${ }^{51}$ The doctrine as it is currently constructed allows employers to make use of privacy rhetoric to justify giving patients only those choices that employers either want to or can comfortably grant, which are-not incidentally - those that comport with job stereotypes and the gender-segregated labor market that Title VII aspires to change. ${ }^{52}$

doctors. Id. Several have filed discrimination cases in the federal courts. See, e.g., Underkofler v. Cmty. Health Care Plan, Inc., No. 99-7838, 2000 U.S. App. LEXIS 19040 (2d Cir. Aug. 4, 2000) (rejecting the plaintiff's claim of sex discrimination because the defendant produced evidence that it terminated the plaintiff on legitimate, nondiscriminatory grounds); Veleanu v. Beth Israel Med. Ctr., No. 98 Civ. 7455, 2000 U.S. Dist. LEXIS 13948 (S.D.N.Y. Sept. 25, 2000) (rejecting the sex and age discrimination claims of a male ob-gyn doctor because the plaintiff did not make a prima facie showing of discrimination and the defendant advanced legitimate, nondiscriminatory reasons for the plaintiff's dismissal). I suspect that courts would not be persuaded that female patients' privacy rights are grounds for BFOQs in these cases, in large part because women have long been attended to by male ob-gyns. It is hard to believe, however, that the privacy claims made are inherently more persuasive in the nursing context-suggesting that what courts are bowing to is preferences that have been constructed by historical sex segregation in the labor market, not "privacy."

50. Brooks v. ACF Indus., Inc., 537 F. Supp. 1122 (S.D. W. Va. 1982). The court found male gender to be a BFOQ for assignment to janitorial duties in a male bathhouse. Id. at 1133. Male janitors were employed to clean the women's bathhouse, but the court dismissed this as inapposite because the men's bathhouse was in more constant use, making it impractical to mandate two times during the day that it would be closed for cleaning. Id. at $1125 \mathrm{n} .8$.

51. City of Philadelphia v. Pa. Human Relations Comm'n, 300 A.2d 97, 104 (Pa. Commw. Ct. 1973) (granting a same-sex privacy BFOQ for Youth Supervisor positions in a male juvenile correction facility).

52. The only prominent exception to this case involves prisons, where courts regularly reject BFOQs, inverting the usual tendency to value privacy over employment rights. In a few early cases, courts granted same-sex BFOQs to exclude women guards from positions where they would have to observe male inmates unclothed. See, e.g., Bowling v. Enomoto, 514 F. Supp. 201, 204 (N.D. Cal. 1981) (following "the trend in other courts" and holding that inmates in an allmale facility have "a right to be free from ... unrestricted observation ... by prison officials of the opposite sex"); Hudson v. Goodlander, 494 F. Supp. 890, 893 (D. Md. 1980) (holding that women guards' interests in equal employment opportunities were not compelling enough to override male inmates' privacy rights in situations where inmates were regularly viewed naked); Iowa Dep't of Soc. Servs., Iowa Men's Reformatory v. Iowa Merit Employment Dep't, 261 N.W.2d 161, 165 (Iowa 1977) (holding, under lowa's analogous BFOQ provision, that a men's prison could refuse to promote women to positions that involved close personal contact with male prisoners, and considering "obvious ... the existence of a personal right of privacy with respect to one's own body and bodily functions"). But many courts have rejected BFOQs that would exclude female guards, generally because employers could not prove that job assignments could not be reorganized to avoid the conflict between privacy and employment rights. See, e.g., Hardin v. Stynchcomb, 691 F.2d 1364 (11th Cir. 1982); Gunther v. Iowa State Men's Reformatory, 612 F.2d 1079 (8th Cir. 1980); Griffin v. Mich. Dep't of Corr., 654 F. Supp. 690 (E.D. Mich. 1982). When female inmates' privacy rights are considered, courts also commonly reject BFOQs. See, e.g., Forts v. Ward, 621 F.2d 1210, 1216 (2d Cir. 1980) (denying a sex-based BFOQ for prison guards assigned to night shifts in women's dormitories because other measures to accommodate inmate privacy concerns wcre available); Everson v. Mich. Dep't of Corr., 222 F. Supp. 2d 864 (E.D. Mich. 2002). But see Robino v. Iranon, 145 F.3d 1109 (9th Cir. 1998) (granting a BFOQ exception to accommodate female inmates' privacy interests and to reduce the risk of sexual conduct between corrections officers and inmates) 


\section{The FaIluRe of SAME-SeX PRIVACy as Privacy LAW}

Of course, if there is something special about "privacy" that justifies the outcome in same-sex privacy cases, then it may be that we-and Title VII-simply ought to accept the deference to preference and the discriminatory effects that it has. Courts often suggest that there is something special about privacy, which both distinguishes it from customer preference and justifies the discriminatory impact that our desire for privacy produces.

Some courts try to draw a special solicitude for privacy from Title VII or its legislative history. If the statute sets privacy apart, courts, of course, would also have reason to do so. Privacy, however, is not mentioned in Title VII, and, as in most sex-related cases, the legislative history offers little assistance in interpreting the statute. ${ }^{53}$ Some courts have made much of stray remarks in the congressional debates about Title VII, such as this comment by Representative Charles E. Goodell:

There are so many instances where the matter of sex is a bona fide occupational qualification. For instance, I think of an elderly woman who wants a female nurse. There are many things of this nature which are bona fide occupational qualifications, and it seems to me they would be properly considered here as an exception. ${ }^{54}$

53. Courts and commentators alike regularly note that the congressional record is of little help in understanding Title VIl's application to sex discrimination. See, e.g., Michael L. Sirota, Sex Discrimination: Title VII and the Bona Fide Occupational Qualification, 55 TEX. L. REV. 1025,1027 (1977). Title VII preceded any serious national consideration of gender discrimination in the workplace, and the stories about how sex came to be included are legion. Sex was added on the last day before Title VII was passed, and many have suggested that the inclusion was something of a joke, intended by opponents of racial desegregation to derail the passage of the bill altogether. See, e.g., Meritor Sav. Bank FSB v. Vinson, 477 U.S. 57, 63-64 (1986) (noting that "[t]he prohibition against discrimination based on sex was added to Title VII at the last minute on the floor of the House of Representatives" and that therefore "we are left with little legislative history to guide us"); Katherine M. Franke, The Central Mistake of Sex Discrimination Law: The Disaggregation of Sex from Gender, 144 U. PA. L. REV. 1, 14 n.48 (1995) (cataloguing numerous judicial references to this history)

54. 110 CONG. REC. 2718 (1964) (statement of Rep. Goodell). The Backus court cites this remark to support the claim that " $[t]$ he legislative history of the act suggests the BFOQ exception is appropriate in this case." Backus v. Baptist Med. Ctr., 510 F. Supp. 1191, 1196 (E.D. Ark. 1981), vacated as moot, 671 F.2d 1100 (8th Cir. 1982). stated:

Other members of Congress made similar remarks. For example, Representative Green

Let us take another example: In a large hospital an elderly woman needs special roundthe-clock nursing. Her family is seeking to find a fully qualified registered nurse. It does not make any difference to this family if the nurse is a white or a Negro or a Chinese or a Japanese if she is fully qualified. But it does make a great deal of difference to this elderly woman and her family as to whether this qualified nurse is a man or a woman. Under the terms of the amendment adopted last Saturday the hospital could not advertise for a woman registered nurse because under the amendment by the gentleman from Virginia [Mr. SMITH] this would be discrimination based on sex. The 
As Deborah Calloway has pointed out, however, the views of individual members of Congress are not typically thought to be persuasive evidence of congressional intent and are particularly unpersuasive when read against the unusual legislative history of Title VII. ${ }^{55}$ It can thus be concluded that "nothing in the language or history of the statute mandates" that courts grant same-sex privacy BFOQs. ${ }^{56}$

Because same-sex privacy BFOQs cannot be securely anchored in Title VII or its legislative history, many courts attempt to anchor them in the law of privacy. Thus, under the test that many courts adopt when considering same-sex privacy cases, employers must not only demonstrate that they are protecting the essence of their business and that there are no reasonable alternatives to a sex-based hiring policy, but also that the customer privacy interests being protected are entitled to protection under the law. ${ }^{57}$ Under this argument, women do not merely prefer female nurses-they have a right to them. So, for example, the court in Fesel insisted that

the attitudes of the nonconsenting female guests at the Home are undoubtedly attributable to their upbringing and to sexual stereotyping of the past. While these attitudes may be characterized as "customer preference," this is, nevertheless, not the kind of case governed by the regulatory provision that customer preference alone cannot justify a job qualification based upon sex. Here personal privacy interests are implicated which are protected by law and which have to be recognized by the employer in running its business. ${ }^{58}$

The trouble in Fesel, as in other cases that involve nursing care, is that every legal right that patients have to privacy is rendered irrelevant by the fact that patients must consent to medical procedures. Medical procedures may not be undertaken without a patient's consent, absent unusual circumstances. ${ }^{59}$ Thus, as Calloway has noted, "[t]o find an intrusion,

suggestion of the gentleman from New York [Mr. GooDELL] helped a great deal, however.

See, e.g., 110 CONG. REC. 2720 (1964) (statement of Rep. Green).

55. Calloway, supra note 46 , at 353 n.123.

56. Id. at 352.

57. See, e.g., Jennings v. N.Y. State Office of Mental Health, 786 F. Supp. 376, 380-81 (S.D.N.Y. 1992), aff'd, 977 F.2d 731 (2d Cir. 1992); Fesel v. Masonic Home of Del., Inc., 447

F. Supp. 1346, 1351 (D. Del. 1978).

58. Fesel, 447 F. Supp. at 1352.

59. Surgery on a person is a technical assault, assault and battery, or trespass unless the patient or some authorized person consented to it, regardless of the skill and care used. See, e.g., Gray v. Grunnagle, 223 A.2d 663, 668-69 (Pa. 1966); Physicians' \& Dentists' Bus. Bureau v. Dray, 111 P.2d 568, 569 (Wash. 1941). In an emergency where immediate action is necessary to protect life, and where it is impractical to obtain actual consent, an inference of consent to medical treatment can be made. See, e.g., Danielson v. Roche, 241 P.2d 1028, 1029-31 (Cal. Dist. Ct. App. 
assault or battery when the medical practitioner is of a different sex than the patient, a court would need to find that the patient did not consent to the treatment. ${ }^{160}$ Nursing care follows the same pattern. ${ }^{61}$ Patients may have an underlying privacy right not to be exposed to the view of others, particularly nonmedical personnel, without their consent, but once again, consent is primary, and sex plays no legally decisive role in the matter. ${ }^{62}$ Privacy torts and criminal actions can no more provide automatic justification for sex-based hiring than they can for race-based hiring. While individuals are free to decline medical care for any reason they like (including the sex, race, or hair color of the provider), it is up to the courts to decide whether we will facilitate such choices where they conflict with antidiscrimination law.

While courts may be right that there is an underlying privacy right at stake in scenes of bodily exposure (which is not, for example, at stake in the airline cases), they are wrong to attribute a sex to this right and to evacuate the central relation between this right and consent. ${ }^{63}$ Once one begins to ask why it is less private to be seen in a state of undress by one sex rather than the other, the foundational logic of the same-sex privacy cases rapidly breaks down. ${ }^{64}$ The fact is, in no other realm of law does the "privacy" of an act depend upon not just who sees which body under what conditions, but also upon what sex the viewer is. The consequences of such a rule in

1952) (holding that no action lies against a doctor who removed allegedly diseased fallopian tubes that were discovered during a consented-to appendectomy).

60. Calloway, supra note 46 , at 345 .

61. Id. at 344 ("“A]lthough many of the procedures and treatments ordinarily performed and administered by nurses and doctors on patients would be tortious acts absent consent, they are not actionable because the patient has consented either expressly or by implication.").

62. See, e.g., Knight v. Penobscot Bay Med. Ctr., 420 A.2d 915, 916 (Me. 1980) (rejecting a claim of intrusion upon seclusion in the labor and delivery room setting, where a patient was exposed to the view of a nonmedical professional without her consent); see also De May v. Roberts, 9 N.W. 146 (Mich. 1881). De May was the first U.S. case decided on grounds of privacy. Mrs. Roberts sued De May, the doctor who attended her birth, because the doctor had brought with him a "young unmarried man, a stranger to the plaintiff and utterly ignorant of the practice of medicine," who carried the doctor's things and attended the delivery. Id. at I46. Here, too, lack of effective consent was central to the court's decision. The claim was of deceit: The plaintiff asserted that she had no idea the aptly named "Scattergood" was not a medical student or doctor, and would not have allowed him to attend the birth if she had known. Id. at 147.

63. Calloway also points out that the imagined privacy violations may be too minimal to be legally actionable, or to outweigh our collective interests in equal employment. Calloway, supra note 46 , at 348 .

64. Indeed, when courts do question this logic, they tend to reject same-sex privacy BFOQs. For example, in Olsen v. Marriot International, Inc., the court rejected a sex-based BFOQ for the hiring of masseuses. 75 F. Supp. 2d 1052 (D. Ariz. 1999). Part of the court's problem with the BFOQ claim was that the employer offered customers a choice of male or female masseuses. Id. at 1064. If customers were being offered a choice, the court reasoned, then preferences, not privacy, must be behind the BFOQ. Id. at 1076. It seems strange, however, to force employers into an all-or-nothing discriminatory choice. Under Olsen's logic, either employers must require all customers to have masseuses of the same sex, or they cannot accommodate customer wishes for privacy. Thus, employers are encouraged to discriminate more than is necessary to meet actual customer preferences in order to fit the constraints of the doctrine. 
tort law, for example, would be bizarre indeed. Imagine a plaintiff photographed in an embarrassing position, say, with her skirt blown up around her at the county fair. ${ }^{65}$ If she brings a tort claim because the photograph is sent to hundreds of members of the Women's Junior League, and only women see the photo, should the court dismiss the case because there was no privacy violation? Individuals have privacy rights in tort regardless of the sex of the intruder. Privacy has often been conceived of as a series of concentric circles, and feminist theorists have noted that these circles always have been implicitly gendered. ${ }^{66}$ In this case, however, the circles are explicitly gendered-indeed, gendered as a matter of law.

Similarly, how can it be more or less private-as opposed to comfortable, intuitive, pleasing, or embarrassing - to be seen in a state of undress by a male nurse rather than by a male doctor? Consider again the bizarre result that this rule of privacy would have upon the privacy tort: Our unwittingly photographed plaintiff would have no legal claim if her picture were circulated to the members of the American Medical Association, but would have a claim if it were circulated to the American Nurses Association. ${ }^{67}$

The claim made in Backus that constitutional privacy rights are at stake in same-sex privacy BFOQ cases is similarly flawed. ${ }^{68}$ The court does not make clear where this right would come from or what its exact nature would be, but consider the possible alternatives. If the court is imagining some sort of penumbral right to same-sex privacy itself, rather than a choice of same-sex privacy (note that Baptist Medical Center did not give its patients a choice of same-sex nurses, but rather assigned all obstetrical patients female nurses $\left.{ }^{69}\right)$, from where does it derive the parameters of this right? (Where, in other words, does privacy get its association with certain genders, bodily zones, and professional statuses?) If Title VII violates this right when it requires hospitals to employ male nurses in labor and delivery rooms, why does it not also violate it in all of the other wards of a hospital or nursing home where patients receive intimate care? Furthermore, a constitutional right to same-sex privacy would imply that such a right must be protected by any healthcare provider that could be considered a state actor for these purposes-but no one claims that a patient not granted a same-sex nurse has a constitutional cause of action against the provider.

65. Daily Times Democrat v. Graham, 162 So. 2 d 474, 476 (Ala. 1964).

66. See, e.g., Anita L. Allen \& Erin Mack, How Privacy Got Its Gender, 10 N. ILL. U. L. REV. 441 (1990).

67. I thank Kenji Yoshino for this point.

68. Backus v. Baptist Med. Ctr., 510 F. Supp. 1191, 1193 (E.D. Ark. 1981), vacated as moot, 671 F.2d 1100 (8th Cir. 1982) ("Defendant contends that if a male nurse is performing these duties, the patient's constitutional right to privacy is violated. We agree with the defendant.").

69. Id. 
Unless the Constitution only guaranteed women same-sex privacy rights, Title VII and providers that could be considered state actors would have to afford men and women the same accommodation of their same-sex privacy. As noted above, in both Fesel and Backus, men regularly received intimate care from females-but neither court took legal, much less constitutional, issue with that fact. ${ }^{70}$ Similarly, would the constitutional right to same-sex privacy apply to nurses but not to doctors? (Recall that in both Backus and Mercy Health Center, the same-sex care rule was applied to nurses but not to doctors. ${ }^{71}$ ) How could it be that women would have a constitutional right to a same-sex nurse but men would not, or that women would have a constitutional right to a same-sex nurse but not to a same-sex doctor?

We might imagine a weaker constitutional right, drawn, for example, from the decisional privacy doctrine, that guaranteed individuals a choice of same-sex privacy. As elaborated in foundational reproductive freedom cases such as Roe v. Wade, ${ }^{72}$ Eisenstadt v. Baird, ${ }^{73}$ and Griswold v. Connecticut ${ }^{74}$ decisional privacy offers us "a constitutional guarantee of a certain spectrum of decisional freedom." J5 Justice Brennan gave the decisional paradigm of privacy its most famous formulation in the contraceptive case of Eisenstadt: "If the right of privacy means anything, it is the right of the individual, married or single, to be free from unwarranted governmental intrusion into matters so fundamentally affecting a person as the decision whether to bear or beget a child." ${ }^{76}$ The same problems apply: Why would the Constitution allow women this choice but not men? Why would this decisional right not apply to encounters with doctors, and to all scenes of cross-sex exposure?

If we shift to the context of the janitorial cases, the claim that the samesex privacy BFOQ is underwritten by constitutional or common-law rights becomes even more fantastic. In Norwood v. Dale, for example, the central legal issue was whether or not the maintenance and management companies of the Standard Oil building in Chicago could refuse to assign a female janitor to a position cleaning men's bathrooms. If the plaintiff had been assigned to the position, as she wished, she would have knocked on the door before entering the bathroom, to warn any of the men inside. The court found that even this alternative impermissibly infringed upon male employees' privacy rights. ${ }^{77}$ No authority is offered to substantiate this

70. See supra note 46 and accompanying text.

71. See supra note 47 and accompanying text.

72. 410 U.S. 113 (1973).

73. 405 U.S. $438(1972)$.

74. 381 U.S. 479 (1965).

75. Kendall Thomas, Beyond the Privacy Principle, 92 COLUM. L. REV. 1431, 1446 (1992).

76. 405 U.S. at 453 (second emphasis added).

77. Norwood v. Dale Maint. Sys., Inc., 590 F. Supp. 1410 (N.D. III. 1984). The court noted: 
asserted right, but as a common-law tort right it makes little sense. Alternatively, the notion that we have a constitutional right not to have a janitor of a different sex knock on the bathroom door is, in its most literal sense, incredible.

There are, however, numerous same-sex privacy cases where the third parties in question do have legally protected privacy rights, either because of independent constitutional provisions like the Fourth Amendment, or because they are not effectively consenting to the surveillance or touching in question. Prisoners, for example, have Eighth Amendment rights that women in privately run labor and delivery rooms do not have. But the prison cases are the exception that proves the rule (that same-sex privacy BFOQs do not have much to do with privacy rights) - because although the argument for same-sex privacy rights in prisons is much stronger than in nursing homes, courts are much less likely to grant same-sex privacy BFOQs in prisons. ${ }^{78}$

The relative reluctance to grant same-sex privacy BFOQs in prisons can perhaps be explained by the fact that prisoners' privacy rights, although extant, are sharply circumscribed. ${ }^{79}$ But this would not explain a striking aspect of some prison cases: Uniquely, when considering same-sex privacy claims in prisons, courts question the logic that conflates notions of privacy with notions of sex. Thus, for example, the court in Gunther v. Iowa State Men's Reformatory rejected a same-sex privacy BFOQ because there were less-discriminatory means available to respect inmates' privacy. ${ }^{80}$ The court did not reach the privacy right claim but insisted that the issue was much more complicated than the defendant claimed:

$[\mathrm{M}]$ ores as to being viewed naked by members of the opposite sex under certain circumstances are bound to change as women become further integrated into the occupational and professional world.... The traditional rule that only male guards may view male inmates

Even the least intrusive alternative, the scheduled closing of the washrooms each day, would still cause stress to tenants and guests when an attendant knocked on the opposite sex's washroom's door to determine if the washroom were in use. A person using the washroom at the time would not know if the attendant would, nevertheless, enter the washroom, not realizing the washroom was still in use. Moreover, the knock may not be heard due to distance from the door or the noise caused by running water. Id. at 1422 .

78. See supra note 52; see also John Dwight Ingram, Prison Guards and Inmates of Opposite Genders: Equal Employment Opportunity Versus Right of Privacy, 7 DUKE J. GENDER L. \& POL'Y 3, 4 (2000) ("[T]here remains a substantial amount of disagreement as to several specific issues, especially visual observation of unclothed inmates, and pat-down, strip, and body cavity searches.").

79. See, e.g., Bell v. Wolfish, 441 U.S. 520,557 (1979) (" $[G]$ iven the realities of institutional confinement, any reasonable expectation of privacy that a detainee retained necessarily would be of a diminished scope.").

80. 462 F. Supp. 952 (N.D. lowa 1979). 
under these conditions may derive from just the type of stereotypical value system condemned by Title VII. ${ }^{81}$

Similarly, in Griffin v. Michigan Department of Corrections, a court rejected a same-sex privacy BFOQ, indicating that the viewing of unclothed inmates was not "intrinsically more odious" when the surveillance was cross-sex. ${ }^{82}$ Rather than wax lyrical about the sacred nature of same-sex privacy, as courts in the labor and delivery room context do, ${ }^{83}$ courts in prison cases are more likely to muse: "How odd it would be to find in the eighth amendment a right not to be seen [naked] by the other sex." 84

Thus, in the prison context, courts resist the conflation of privacy rights with same-sex privacy rights-in some cases even noting that sexing the privacy right is problematic because it reinforces discriminatory gender meanings that Title VII intends to change. ${ }^{85}$ In nonprison settings, even where litigants question the link between sex and privacy, courts summarily dismiss such questions. ${ }^{86}$ There could be many reasons for this; I will suggest just two. First, prison cases much more regularly involve claims about men's same-sex privacy interests than do other same-sex privacy cases. ${ }^{87}$ Courts may be more likely to resist the automatic sexing of the privacy norm where the privacy of men is at stake because men's bodies are seen as inherently less private than women's - an issue to which we will return shortly. But courts also reject women's privacy interests in the prison setting, suggesting another reason: Prisoners' bodies are seen as less sacrosanct than the bodies exposed in cases like Backus and Norwood.

If we resist the temptation to reach for the "obvious," the following fact is startlingly clear: Same-sex privacy doctrine cannot be defended with recourse to the law of privacy. In many cases, the third parties in question have no relevant privacy rights. Even where they do have such rights, it is

81. Id. at 956 n.4 (citation omitted).

82. 654 F. Supp. 690, 701 (E.D. Mich. 1982).

83. See, e.g., Backus v. Baptist Med. Ctr., 510 F. Supp. 1191, 1193 (E.D. Ark. 1981) (noting that "the body involves the most sacred and meaningful of all privacy rights"), vacated as moot, 671 F.2d 1100 (8th Cir. 1982).

84. Johnson v. Phelan, 69 F.3d 144, 148 (7th Cir. 1995).

85. See supra note 81 and accompanying text.

86. For example, in a suit challenging sex-based employment practices in mental hospitals in Michigan, members of Local 567 insisted that " $[t]$ he violation of the right of privacy would be just as pronounced were the right defined in a constitutional sense or in the traditional tort sense, without regard to the sex of the transgressor." Local 567 Am. Fed'n of State, County \& Mun. Employees v. Michigan, 635 F. Supp. 1010, 1013 (E.D. Mich. 1986) (quoting the plaintiffs" pleadings). The court rejected this, saying:

Not only is this an unrealistic view of human mores in this country, but it is contrary to the law. Obviously most people would find it a greater intrusion of their dignity and privacy to have their naked bodies viewed (or any number of personal services performed) by a member of the opposite sex.

Id. at 1013-14.

87. See supra note 52. 
not self-evident that there is or ought to be a link between those privacy rights and sex.

\section{REAL SEX AND SEXUAL PROFILING}

It is clear that there is no law of privacy that demands that courts read same-sex privacy BFOQs into Title VII, nor does the statute or legislative history give authoritative reason to do so. Nonetheless, there is a logic to these cases, which has two strands. First, courts consider a desire for samesex privacy as a "fact" of biological sex or a deep part of the cultural construction of gender, and therefore something that the law should not aspire to change. Second, courts engage in a kind of sexual profiling, circumscribing a zone where gender, sexuality, and notions of physical and psychic safety overlap. Under this view, the same-sex privacy BFOQ is a concession to the way people experience cross-sex bodily exposure as a threat or risk.

\section{A. Protecting Sex/Gender}

Some courts justify same-sex privacy BFOQs by invoking the biological "fact" of sex itself. For example, in City of Philadelphia $v$. Pennsylvania Human Relations Commission, the court protested:

The Commission suggests that no facts were adduced by the City in support of its contention that personal contact under very intimate circumstances must be limited to contacts between persons of the same sex. Once again, the Commission seeks facts in an area where facts are not available. . . The biological difference between men and women which in turn produce [sic] psychological differences are the facts that justify limiting personal contact under intimate circumstances to those of the same sex. ${ }^{88}$

Thus, according to this court, the syllogism is simple: Biology begets physiology begets law. "Sex" itself, understood as biological difference, becomes the core of the private. Under this view, same-sex privacy is a Title VII-free zone because it protects bodies themselves, that is, biological sex difference or "real sex" itself-not "gender," or social meaning, or stereotypes, or any of the other things that Title VII properly aims to change. As the Backus court put it: "LLaws forbidding discrimination in hiring on the basis of sex do not purport to erase all differences between the

88. City of Philadelphia v. Pa. Human Relations Comm'n, 300 A.2d 97, 103 n.7 (Pa. Commw. Ct. 1973). 
sexes. These laws recognize that there are jobs for which one sex is inherently and biologically more qualified." ",89

Further evidence that these cases are driven by biologized notions of sex is provided by the few nonprison cases in which courts have rejected same-sex privacy BFOQs. Courts are evidently reluctant to grant a BFOQ where job duties do not include direct genital contact or viewing. In EEOC $v$. Sedita, a fitness center called "Women's Workout World" claimed that privacy needs justified its refusal to hire men as managers, assistant managers, and instructors. ${ }^{90}$ The district court rejected this claim, despite the fact that the fitness center provided as much evidence about customer preferences as the defendants in Backus and Mercy had. ${ }^{91}$ Similarly, in EEOC v. HI 40 Corp., a court denied a BFOQ defense to a weight-loss center charged with sex discrimination in the hiring of counselors. In this case, the defendant insisted that some of her clients, who were overwhelmingly women, objected to having bodily measurements taken by men, ${ }^{92}$ and did not want to be counseled by men about weight loss and their associated emotional and relationship troubles. ${ }^{93}$ The court dismissed customers' privacy interests in the measurements as "minimal," tersely rejected the idea that same-sex privacy extended to the counseling function. ${ }^{95}$

In Olsen v. Marriot International, Inc., when Marriott's Camelback Inn attempted to justify sex-based hiring of masseuses on privacy grounds, another federal court was similarly unpersuaded:

Although massage at the Marriott involves touching and manipulation of intimate areas such as abdominals and inner thighs, ... the legitimate job duties of a massage therapist ... do not include viewing or touching female clients' breasts or either

89. Backus v. Baptist Med. Ctr., 510 F. Supp. 1191, 1194 (E.D. Ark. 1981) (quoting $P a$. Human Relations Comm'n, 300 A.2d at 103 n.7), vacated as moot, 671 F.2d 1100 (8th Cir. 1982).

90. EEOC v. Sedita, 755 F. Supp. 808 (N.D. Ill. 1991), vacated by 816 F. Supp. 1291 (N.D. Ill. 1993).

91. The court found fault with the fact that the defendant did not prove exactly how many customers would object, exactly what they would object to, and whether their objections would truly result in a loss of business. "The defendant must prove that clients would stop patronizing his business if members of the opposite sex are hired." Id. at 811 . In Backus, the court accepted a "factual basis" that consisted of testimony from one patient and eight medical professionals, who testified about their impressions of patient preferences. Backus, 510 F. Supp. at 1196. In Mercy Health Center, the court relied upon a written survey of patients with no comment upon its method or questions, and upon complaints that came not from patients but from the two male doctors in the ob-gyn department. EEOC v. Mercy Health Ctr., 29 Fair Empl. Prac. Cas. (BNA) 159,163 (W.D. Okla. 1982).

92. These measurements were consensual and nonmandatory, but if a woman chose to have them done, they involved physical touching at the neck, shoulders, bust, ribs, waist, hips, thigh, knee, calf, and ankle. EEOC v. HI 40 Corp., 953 F. Supp. 301, 303 (W.D. Mo. 1996).

93. Id.

94. Id. at 304 .

95. Id. 
male or female clients' genitalia.... The massage context is dramatically different from a situation in which legitimate job duties necessitate washing a patient's genitalia or viewing a thirdparty's genitalia .... ${ }^{96}$

Olsen only involved an interim order, so the court was not deciding as a matter of law that there could be no sexual privacy interests at stake in the massage context. It did, however, find enough doubt to deny defendants' motion and to imply that Marriott's chances of success were slim. The reason: Massage does not involve genital contact, and, in search of a principle to limit the breadth of sex-based privacy claims, the court in Olsen fixed on the "privates." Massage may involve much more deeply erotic and intimate associations than a pelvic exam, but the Olsen court was unwilling to accept the contextual and decisional values of sexual privacy that the defendant asserted. Thus, the court rejected the claim that anything other than genital physicality (e.g., a history of sexual abuse, or a sense of comfort) could generate a privacy interest. ${ }^{97}$

All of these cases have a common denominator: The courts use a particular bodily zone-the "privates"-to delineate the proper scope of the same-sex private. The genitals stand here as the essence of the private and the location of fixed sexual difference-that is, the difference that Title VII cannot, and should not, reach.

This view, however, is puzzling. There is no foreordained or necessary relationship between anatomy and law. Indeed, equal protection law often purports to take precisely the opposite view of biology: that the law properly intervenes only in response to biologically immutable characteristics. The fact is, biological difference itself tells us nothing about the difference this difference makes. There are innumerable "biological" differences-hair color, age, or height, for example-that would not support privacy claims. Among the same-sex privacy cases, there are biological differences that make no difference, as between female nurses and male patients or between female patients and male doctors. ${ }^{98}$

Indeed, it is not possible to make sense of same-sex privacy cases without understanding that genitals are much more than just biology, part of the body. Consider the claim, put forth in Mercy Health Center, that many of the delivery room nurses' duties involve some "invasion of the mother's body." 99 Could we not conceive of many other wards in the hospital as involved in equally if not more "invasive" procedures? Might not open

96. Olsen v. Marriott Int'1, Inc., 75 F. Supp. 2d 1052, 1069 (D. Ariz. 1999).

97. Id. at 1064.

98. See supra note 46 and accompanying text.

99. EEOC v. Mercy Health Ctr., 29 Fair Empl. Prac. Cas. (BNA) 159, 162 (W.D. Okla. 1982). 
heart surgery, or an appendectomy, be more invasive than a pelvic exam? Why do we not have privacy interests in the context of brain surgery? The brain is only matter, one might argue; after all, you cannot see anything private by looking at a brain. But what does one see in a pelvic exam that is private? By emphasizing the "invasion" of the genitals, the Olsen court suggested that they are linked to our person and personality in a way that even our brains are not. They are, in an unspoken way, gender identity itself. By protecting zones of the genitals, then, courts protect gendered constructions of sex, not sex itself-it being in effect impossible to separate the two. ${ }^{100}$

It is thus not possible to adequately defend same-sex privacy with reference to anatomical difference itself. Some courts concede that fact: For example, in Backus, the court admitted that same-sex privacy was a cultural matter, but insisted that it was a deeply cultural matter, such that exposing one's body to the opposite sex "clashes with a deeply held social, moral and emotional bias pervading western culture." "101 The court in Local 567 went even further, stating that the same-sex privacy norm was

in fact a cultural thing. But there is no reason why cultural attitudes cannot be protected.... [S]ince the essence of the matter here under consideration is personal privacy, there are no imperatives, no "shoulds" or "shouldn'ts." That is the essence of privacy, that there is no norm. It is private. ${ }^{102}$

Here, the dividing line between customer preference and privacy is marked by the depth of the biases held, and the appellation "privacy" provides the curtain beyond which courts cannot look. The genital privates are where antidiscrimination law stops trying to remake gender, not because nature decrees it, but because culture decrees it. Under this reasoning, same-sex privacy may be a customer preference, but Title VII should defer to it because it is a really strong customer preference. ${ }^{103}$ As Lex Larson's treatise puts it, "[G]iving respect to deep-seated feelings of personal privacy involving one's own genital areas is quite a different matter from catering to the desire of some male airline passengers to have a little diluted sexual titillation from the hovering presence of an attractive female flight attendant." $" 104$

100. See JUdith BuTLER, Gender Trouble 7 (1990); Franke, supra note 53, at 5 .

101. Backus v. Baptist Med. Ctr., 510 F. Supp. 1191, 1195 (E.D. Ark. 1981) (quoting In re Long, 127 Cal. Rptr. 732, 736 (Ct. App. 1976)), vacated as moot, 671 F.2d 1100 (8th Cir. 1982).

102. Local 567 Am. Fed'n of State, County \& Mun. Employees v. Michigan, 635 F. Supp. 1010,1014 n.7 (E.D. Mich. 1986).

103. See, e.g., Wilson v. Southwest Airlines Co., 517 F. Supp. 292, 301 n.23 (N.D. Tex. 1981) (indicating in dicta that "[c]ustomer preference may ... give rise to a [BFOQ] for one sex where the preference is based upon a desire for sexual privacy").

104. 3 LARSON, supra note $8, \S 43.03[3][\mathrm{b}]$, at $43-10$. 
This position does not have the logical deficiencies of the same-sexprivacy-as-biological-law argument. But it does raise a number of questions. How do we (or courts) know which cultural notions of gender are beyond the reach of Title VII? If the decisive matter is how "deeply held" a gender norm is, how do we measure this? (Note too how little indication there is in same-sex privacy cases that anyone involved is committed to vigorously testing the contours or depths of customer preferences. ${ }^{105}$ ) What does it mean for a court to establish parts of the world as really male and really female? In many other areas, courts characterize Title VII as deeply serious about preventing "cultural" notions of gender from underwriting discrimination in the labor market. Why are cultural notions, for example, about women's suitability for manual labor, or men's suitability for care work, not a part of the received wisdom about gender that Title VII should respect? (Alternatively, don't same-sex privacy cases reinforce precisely these kinds of meanings about sex? ${ }^{106}$ Is it because these are not as "deeply" a part of gender as is genital modesty? Even if we accepted that contentious proposition, why would the kinds of privacy interests being claimed in the massage or fitness scenario be less real or important than those claimed in the delivery room? Why should the law protect our deeply culturally sanctioned wish for bodily modesty, but not also protect our deeply culturally sanctioned desire to discuss or display certain parts of our gendered vanity or vulnerability only around members of the same sex (as in the weight-loss and spa cases)? What does it mean for the law to delineate a zone of gender that is beyond its reach and allow it to be used to justify discrimination? Let us postpone these questions for a moment and explore the other justification that materializes in same-sex privacy cases: physical and psychological safety.

\section{B. Threat and Sexual Profiling}

The other logic of same-sex privacy cases involves sexual profiling: Courts allow employers to use sex as a criterion in making employment decisions because they believe that sex is intimately associated with our sense of identity, risk, and threat. Under this logic, it is not "sex itself" that is being respected. Instead, courts are trying to respect individuals for whom sex means certain fundamental, mysterious, and sometimes dangerous things. The differential distribution of risk of assault between women and men would then help explain why same-sex privacy rules are generally not applied to men and why this fact does not give courts pause.

105. See infra note 134.

106. See supra note 48 and accompanying text. 
This line of reasoning is most evident in cases involving children or individuals incarcerated in institutions or in psychiatric care, where the psychological and physical vulnerability of individuals is most readily apparent. So, for example, in City of Philadelphia v. Pennsylvania Human Relations Commission, the court approved a same-sex privacy BFOQ, insisting that the psyches of the children in residence would be put at risk by cross-sex viewing or contact:

If sex is not "relevant" in the supervision of children who range in age from seven to sixteen in various stages of undress, where can it be?

To subject a girl in this age group to a thorough search of her body by a male supervisor could cause not only a temporary traumatic condition, but also permanent irreparable harm to her psyche. It is no different where females supervise male juveniles. To have a woman supervisor observe daily showers of the boys at a time in life when sex is a mysterious and often troubling force is to risk a permanent emotional impairment under the guise of equality. ${ }^{107}$

Similarly, in Healey v. Southwood Psychiatric Hospital, the court allowed a same-sex privacy BFOQ for the position of child care specialist, indicating that "due to both therapeutic and privacy concerns, Southwood is an institution in which the sexual characteristics of the employee are crucial to the successful performance of the job of child care specialist." 108 The court emphasized therapy much more than privacy, contending, for example, that "[r] ]ole modeling' . . is an important element of the staff's job, and a male is better able to serve as a male role model than a female and vice versa," and that "children who have been sexually abused will disclose their problems more easily to a member of a certain sex."109 Indeed, the court's "privacy" concerns seem to add little to its notion of therapeutic necessity, except for the specter of bodily exposure. Explaining the "privacy concerns" that the court found sufficient for a BFOQ, the court said, "[A]dolescent patients have hygiene, menstrual, and sexuality concerns which are discussed more freely with a staff member of the same sex. Child patients often must be accompanied to the bathroom, and sometimes must be bathed."

107. City of Philadelphia v. Pa. Human Relations Comm'n, 300 A.2d 97, 102-03 (Pa. Commw. Ct. 1973).

108. 78 F.3d 128, 134 (3d Cir. 1996).

109. Id. at 133 .

110. $1 d$. 
But what, exactly, do the courts in these two cases think is going to happen to these children if their same-sex privacy is invaded? Why is being seen by someone of the opposite sex itself a harm-and what is it a harm to? In both of these cases, the answer appears to have to do with the state of vulnerability around sex and sexual identity in which courts perceive children - and in particular these children - to be. It is as if, because of either abuse or the "mysteries" of the teenage years, their senses of gender and sexuality are too fragile to withstand any variation from accepted norms of modesty and sexuality. To the extent that this is what drives these cases, they simply return us to the questions above: Ought courts to be in the business of defending norms of gender themselves-and which ones ought they defend?

In both of these cases, the courts insisted that individuals have the right to grow up as properly gendered and modest individuals, but something else was also clearly at work - an unspoken but looming concern about sexual abuse. In all same-sex privacy cases, I would contend, anxiety about crosssex bodily contact and viewing in some sense reflects fears and realities of sexual abuse or harassment. In other words, courts that grant same-sex privacy BFOQs are responding to the notion that allowing physical exposure between people is more dangerous when they are of different sexes because they are more likely to abuse one another or more likely to have been abused by someone of a different sex.

Litigants raise the specter of abuse regularly, particularly in more recent cases. In Healey, the fact that many of the children in question had been abused before was clearly important to the court. ${ }^{111}$ Marriott's Camelback Inn attempted to defend its sex-based hiring with reference to the fact that some clients had experienced abuse and would be uncomfortable with a masseuse of the same sex as their abuser. ${ }^{112}$ The cases that raise the issue of sexual threat and abuse in starkest fashion are those where prison administrators seek same-sex privacy BFOQs to exclude male guards from female inmates' housing units, in the context of serious and ongoing allegations of sexual abuse. ${ }^{113}$ In the most recent such case, Everson $v$. Michigan Department of Corrections, prison administrators excluded male corrections officers from women's housing units shortly after high-profile cases alleging widespread sexual and physical abuse of female inmates were settled. ${ }^{114}$ According to the reassignment request that prison

111. Id. (" $[\mathrm{C}]$ hildren who have been sexually abused will disclose their problems more easily to a member of a certain sex....").

112. Olsen v. Marriott Int'l, Inc., 75 F. Supp. 2d 1052, 1064 (D. Ariz. 1999).

113. Robino v. Iranon, 145 F.3d 1109 (9th Cir. 1998); Everson v. Mich. Dep't of Corr., 222 F. Supp. 2d 864 (E.D. Mich. 2002).

114. See, e.g., Nunn v. Michigan Department of Corrections, No. 96-CV-71416, 1997 U.S. Dist. LEXIS 22970 (E.D. Mich. Feb. 4, 1997). For more on these cases, see Everson, 222 F. Supp. $2 \mathrm{~d}$ at 871-72. For more on the history of abuse in Michigan's prisons, see Iman R. Soliman, Male 
administrators filed with the Michigan Department of Civil Services, the reasons for the exclusion of male corrections officers included security, the prevention of spurious allegations of abuse, and the belief that the changes adopted to prevent abuse would "not eliminate inappropriate behavior or sexual misconduct." $" 115$

The Michigan Department of Corrections contended that as long as there were male corrections officers in the women's housing unit, there would be assaults - in other words, they engaged in sexual profiling. The court rejected the argument, but not its premise. They insisted that there was both no reason to suspect that "all, or substantially all, males are not able to perform safely and efficiently the duties ... in the housing units in the female prisons," 116 and that the fact that "[t]he few [male officers] that are likely to be involved [in improper activities] does not justify a BFOQ requirement in the face of federal and state law clearly prohibiting gender based discrimination." 117

How far we have come from the corporate bathroom in Norwood or the labor and delivery room in Backus. The defendant in Everson sought a same-sex privacy BFOQ out of the sense that only the exclusion of men from certain employment opportunities could guarantee safety for female inmates. This is sexual profiling, and it surely has to do with "stereotyped characterizations of the sexes." 118 As the court insisted, not all men would abuse inmates; only some might. And it poses the most difficult question that the same-sex privacy doctrine has yet been asked to answer. It is generally claimed that Title VII strongly resists sexual profiling. For example, the Supreme Court has refused to allow employers to use sex as a proxy for strength - even though, according to the Court, the strength-sex correlation might be fairly accurate. ${ }^{119}$ But where the cost of rejecting sexual profiling is potentially so acute, and is also borne disproportionately by women, ought Title VII take a different view of it?

Officers in Women's Prisons: The Need for Segregation of Officers in Certain Positions, 10 TEX. J. WOMEN \& L. 45 (2000).

115. Everson, 222 F. Supp. $2 \mathrm{~d}$ at 877.

116. Id. at 895 . Although that finding was sufficient to justify the holding, the court also held that the prison had not provided enough statistical evidence to suggest that other, less discriminatory measures could not be employed to meet the desired ends. Id.

117. Id.

118. Dothard v. Rawlinson, 433 U.S. 321,333 (1977).

119. UAW v. Johnson Controls, lnc., 499 U.S. 187, 202 (1991) (commenting on Dothard). EEOC regulations make a similar point, deeming a BFOQ unwarranted in situations involving "[t]he refusal to hire an individual based on stereotyped characterizations of the scxes." 29 C.F.R. $\S 1604.2$ (a)(1)(ii) (2001). According to the regulations:

Such stereotypes include, for example, that men are less capable of assembling intricate equipment; that women are less capable of aggressive salesmanship. The principle of nondiscrimination requires that individuals be considered on the basis of individual Id.

capacities and not on the basis of any characteristics generally attributed to the group. 


\section{REMAKING SAME-SEX PRIVACY NORMS}

Same-sex privacy cases construct a limit to Title VII's strong command to remake the world of gender where it conflicts with employment equity. They declare that the norm of same-sex privacy or modesty between the sexes is beyond the reach of Title VII-except in the context of prisons. But is this legitimate? Is this a norm that we, or courts, ought to be protecting from Title VII? Post puts the problem best:

Gender is highly salient in matters of privacy. The sex of the person by whom we are seen or touched normally matters very much to us. For this reason, the court in Fesel did not imagine the plaintiff as an individual whose sex was irrelevant, but instead as a fully sexed person. Even though the employer in Fesel, like the employer in Wilson, sought to maintain a single-sex work force, Fesel accepted the gender-specific stereotypes implicit in the privacy norms invoked by the nursing home, and the court incorporated these stereotypes into the BFOQ exception of Title VII.

Fesel illustrates how Title VII does not simply displace gender practices, but rather interacts with them in a selective manner. The case forces us to ask which gender practices are to be reshaped by Title VII, in what contexts, and in what ways. ${ }^{120}$

If these cases force us to ask these questions, can reading them help us answer them? I contend that it can-but only if we read them not only for their immediate discriminatory impact (for example, whether the doctrine disadvantages women in the labor market as it is applied), but also for the gendered meanings that they instantiate and protect, and for what they imply about the costs of changing any particular set of gendered meanings.

Reading same-sex privacy cases in this way suggests two principles that should determine whether a particular gender norm ought to be subject to or protected by Title VII. First, gender norms ought to be contested where they materially or symbolically subordinate those that Title VII was established to defend. But same-sex privacy cases also highlight the costs associated with using the law to change gender norms. The second principle, then, is that we should consider the costs that changing norms imposes upon those that antidiscrimination law seeks to protect to decide when and how to attempt these changes.

120. Post, supra note 29 , at 26 (footnote omitted). 


\section{A. Material and Symbolic Subordination}

It has become commonplace to articulate two competing definitions of antidiscrimination: one based upon an "antidifferentiation" principle, which sees legally authorized classifications as discriminatory, and the other based upon an "antisubordination" principle, which holds that "both facially differentiating and facially neutral policies are invidious only if they perpetuate racial or sexual hierarchy." ${ }^{21}$ This distinction was developed predominantly around the fault line of affirmative action cases, in order to make the (in my view, entirely legitimate) point that "[i]t is more invidious for women or blacks to be treated worse than white men than for men or whites to be treated worse than black women under this perspective, because of the differing histories and contexts of subordination faced by these groups." 122

But to ask the question "antidifferentiation or antisubordination?" is already to purport to answer precisely the question at stake in same-sex privacy cases: "When is differentiation subordinating?" One obvious answer is when differentiation results in materially worse outcomes for women. Thus, in same-sex privacy cases we could measure the projected impact of the same-sex privacy rule upon women's participation in the labor market and object to the norm because, for example, in the prison context, "privacy considerations reduce female employment opportunities because approximately ninety-five percent of the prisoners are male," because, in the nursing context, they reproduce the structure of demand that has relegated women to lower-paid care work. ${ }^{124}$

There is, however, a less obvious answer suggested by the same-sex privacy cases. These cases suggest that we must measure discrimination not only materially, but also symbolically. They also indicate that we should consider symbolic subordination not as a derivative or second-order form of discrimination, but as a source of material subordination. ${ }^{125}$ Thus, to decide whether it is subordinating or discriminatory for the law to protect a core of "common sense"126 gender meanings, we must measure not only the direct

121. Ruth Colker, Anti-Subordination Above All: Sex, Race, and Equal Protection, 61 N.Y.U. L. REV. 1003, 1007-08 (1986).

122. Id. at 1009 .

123. Calloway, supra note 46 , at 331 .

124. See supra notes $48-52$ and accompanying text.

125. I use the term "symbolic" to designate the order of language and representation. The notion that the symbolic order does not represent the real order, but rather produces it, is typically associated with linguistic and semiotic theory as articulated, for example, by Jacques Lacan. See Jacqueline Rose, Introduction-II, in FEMALE SEXUALITY: JACQUES LACAN AND THE ÉCOLE FREUDIENNE 27, 31-32 (Juliet Mitchell \& Jacqueline Rose eds. \& Jacqueline Rose trans., 1985). Ct. 1973). 
impact upon the labor market caused by respect for such norms, but also the kinds of legal subjects that these norms call forth.

Consider, then, the gendered meanings that same-sex privacy cases establish. First, they construct women's bodies as more private than men's, by insisting that women have an inviolable "right" to same-sex privacy that men do not. Employers regularly treat the sexual privacy rights of men and women very differently in sexual privacy cases, ${ }^{127}$ in a way that resonates uncomfortably with the historical construction of women's bodies and concerns as the domain of the private rather than public sphere. ${ }^{128}$

It is well established that the legal construction of the family as a sphere of "privacy" has facilitated the ongoing physical abuse of women within the home. ${ }^{129}$ To put this in symbolic terms, the problem with the privatization of the domestic sphere is not just that it results in an immediate failure to protect women's right to bodily integrity, but also that it constructs women as semiprivatized subjects, subjects of a kind of violence that can have no political articulation.

In the same-sex privacy context, when courts treat women's bodies as more private than men's, they are not forbidding the law from taking cognizance of violence against women. (In fact, they may implicitly be doing just the opposite, as we shall discuss momentarily.) But the symbolic order that courts construct is nonetheless problematic because it relies upon notions of bodily modesty and chastity that have long operated to deny women sexual autonomy. As privacy scholar Anita Allen has noted, "Conventions of female chastity and modesty have shielded women in a mantle of privacy at a high cost to sexual choice and self-expression." ${ }^{\prime 130}$ Consider the meanings that the famed sexologist Havelock Ellis attached to

127. See, e.g., Forts v. Ward 621 F.2d 1210 (2d Cir. 1980); Backus v. Baptist Med. Ctr., 510 F. Supp. 1191 (E.D. Ark. 1981), vacated as moot, 671 F.2d 1100 (8th Cir. 1982). But see Jones v. Hinds Gen. Hosp., 666 F. Supp. 933 (S.D. Miss. 1987) (supporting an employer's dismissal of female nurses rather than male orderlies because there were more nurses than orderlies, and orderlies had to be on hand to perform "intimate functions" for male patients).

128. For many feminists, "privacy" is inherently suspect, and "connote[s] conditions of female confinement and subjugation in the home." Anita L. Allen, Taking Liberties: Privacy, Private Choice, and Social Contract Theory, 56 U. CIN. L. REV. 461, 470 (1987) (referring specifically to Susan Moller Okin and Jean Bethke Elshtain); see also CATHARINE A. MACKINNON, FEMINISM UNMODIFIED 93, 101-02 (1987) (arguing that privacy rhetoric reinforces the "separate spheres" ideology that has traditionally subordinated women); Rhonda Copelon, Unpacking Patriarchy: Reproduction, Sexuality, Originalism, and Constitutional Change, in A LESS THAN PERFECT UNION: ALTERNATIVE PERSPECTIVES ON THE U.S. CONSTITUTION 303, 314 (Jules Lobel ed., 1988) (contending that the privacy doctrine "has reinforced the original distinction between public and private that has been essential to the patriarchal differentiation of male from female, the family from the state and market, the superior from the inferior, the measure from the other").

129. As Reva Siegel has pointed out, when husbands lost the legal right to physically "chastise" their wives, judges regularly cited privacy as reason to continue to grant husbands immunity to charges of assault. Reva B. Siegel, "The Rule of Love": Wife Beating as Prerogative and Privacy, 105 YALF. L.J. 2117, 2150-74 (1996).

130. Allen, supra note 128 , at 471 . 
modesty, that "especially ... feminine trait." ${ }^{\text {"131 }}$ Modesty, according to Ellis, is "closely connected with the more passive part in sex activity played generally by the female," 132 a product of "the primitive animal gesture of sexual refusal on the part of the female," as well as of disgust, fear, the repression and arousal of male desire, and "the conception of women as property." 133 To the extent that same-sex privacy cases turn on notions of natural and essential female modesty, then, they lend authority to, rather than disrupt, a troublesome set of meanings. ${ }^{134}$

These cases also cast feminine modesty as something ancillary to law, when it might more properly be considered a product of law. Consider, for example, the history of sumptuary laws, which regulated the kind of clothing that people could wear. These laws were "enforced overwhelmingly against women,", 135 and "exhibited a preoccupation, in the name of modesty and morality, with female necklines, and, to a lesser extent, with exposed backs." ${ }^{\text {136 }}$ They were preoccupied with women's legs too: In the 1920s, when a fashion for shorter skirts hit the United States, several states introduced bills to regulate them, requiring, for example, that skirts not be shorter than three inches above the ankle. ${ }^{137}$ The norms about bodily exposure that the courts identify as "natural" are thus anything but that.

131. HAVELOCK ElLIS, PSYCHOLOGY OF SEX 336 (1946).

132. Id at 337.

133. Id. at 36 .

134. Consider, for example, that among the evidence the court in Backus held proved a "factual basis" for the BFOQ granted in that case was one doctor's testimony that half of her female patients "and even a greater percentage of their husbands" would object to a male nurse. Backus v. Baptist Med. Ctr., 510 F. Supp. 1191, 1196 (E.D. Ark. 1981), vacated as moot, 671 F.2d 1100 (8th Cir. 1982). Note too how the modesty regime's denial of female agency resonates with the coercive cast of same-sex privacy cases. In cases like Backus, Fesel, and Mercy Health Center, same-sex privacy is a command, not a choice. By allowing hospitals to discriminate against all male nurses, courts promote a regime where no woman will have the option of choosing a male nurse, and where women are cast as unable to assert effectively their own interests in same-sex privacy. In these cases, courts spend little time asking after the expressed interests of the women whose privacy is ostensibly at stake, instead allowing employers, medical professionals, and the courts themselves largely to decide what women want. For example, to provide a "factual basis" that hiring male nurses would fatally undermine their business, Baptist Medical Center presented evidence from one patient and eight medical professionals, who testified about their impressions of patient preferences. $I d$. at 1196 . The only official complaints cited in Mercy Health Center came not from patients, but rather from the two male doctors. 29 Fair Empl. Prac. Cas. (BNA) 159, 161 (W.D. Okla. 1982). By insisting that women must have female nurses, and by not demanding rigorous evidence of female patients' preferences, courts suggest that it is not important to ask women whether they want same-sex privacy. The norm of same-sex privacy that courts instantiate operates as a kind of "coerced privacy," as Anita Allen defines the term. Anita L. Allen, Coerced Privacy, 40 WM. \& MARY L. REV. 723,729 (1999) (defining coerced privacy as a norm imposed "to make sure everyone lives in accordance with a particular vision of privacy").

135. AlAN HUNT, GOVERNANCE OF THE CONSUMING PASSIONS 214 (1996).

136. Id. at 222 .

137. Id. at 234 (citing JAMES LAVER, MODESTY IN DRESS: AN INQUIRY INTO THE FUNDAMENTALS OF FASHION (1969)). 
Same-sex privacy also has symbolic implications beyond the context of sex. By authorizing the exclusion of male nurses in contexts where male doctors are the rule, same-sex privacy doctrine implicitly endorses a troubling regime of privacy that is shot through with discriminatory attitudes about class and possibly race. ${ }^{138}$ The presumption is, of course, that women do not mind male doctors but they do mind male nurses-just as courts like the one in Fesel insist that men do not mind female nurses. But this is plainly less a judgment about "privacy" than about the comparative likelihood of those lower down in status hierarchies to be professional with, and respectful of, clients. The flip side of this point is represented in the prison cases. Courts have been more solicitous of the privacy interests of white collar men who fear that a cleaning woman might knock on their bathroom door ${ }^{139}$ than of the privacy interests of women and men incarcerated in prisons that are often the site of severe violations of physical and sexual integrity. ${ }^{140}$ Part of the reason, I contend, is that "common sense" norms of gender are much more likely to seem persuasive and important to protect in genteel settings like nursing homes or the Standard Oil building than in settings such as prisons.

Third, cases like Backus foreclose the notion that people experience their bodies, genders, and sexualities in different ways. When courts base same-sex privacy decisions upon "[t]he biological difference[s] between men and women which in turn produce psychological differences," 141 they insist that sexes, bodies, and, implicitly, sexualities line up in consistent and predictable ways. By treating same-sex privacy as if it were a product of biology or uncontestable gender norms, courts create an inner truth of sex, mobilizing the resources of the law to disavow the law's role in constructing these same norms. Same-sex privacy cases partake of what Katherine Franke calls a legal belief in the truth of "biological sexual difference" and "sexual identity [that] inevitably reifies masculinity as the natural expression of male subjectivity and femininity as the natural expression of female subjectivity." 142

138. One cannot tell anything certain about the race of employees and third parties in these cases. It would stand to reason, however, given the fact that the labor market is also stratified by race, that the perceived differences between male nurses and male doctors also reflect perceptions about race, privacy, and sexual aggression or danger.

139. Norwood v. Dale, 590 F. Supp. 1410,1422 (N.D. Ill. 1984).

140. See, e.g., Forts v. Ward, 621 F.2d 1210, 1216 (2d Cir. 1980) (holding that women inmates' privacy interests could be adequately protected by pajamas and fifteen-minute periods where inmates were allowed to cover the windows to their cells). On the severe sexual abuse endemic to women's prisons, see AMNESTY INT'L, NOT PART OF MY SENTENCE: VIOLATIONS OF THE HUMAN RIGHTS OF WOMEN IN CUSTODY (1999), at http://www.web.amnesty.org/ai.nsf/ index/AMR510011999.

141. City of Philadelphia v. Pa. Human Relations Comm'n, 300 A.2d 97, 103 n.7 (Pa. Commw. Ct. 1973).

142. Franke, supra note 53 , at 4. 
This refusal to acknowledge or account for variation in sexual identity and sexuality dismisses many people's experiences of sexuality and sex. While we should pause before adopting wholesale the notion that norms of same-sex privacy are at their core about sexuality, ${ }^{143}$ it is also the case, as one court has stated, that the same-sex privacy norm "appear[s] to assume that all of the relevant actors are heterosexual." ${ }^{144}$ Same-sex sexual privacy doctrine participates in the closeting of homosexuality because it presumes everyone to experience their gender, their sexuality, and their bodies in the same way, the "right" way. The insistent heterosexual presumption behind the same-sex-as-private norm is insensible to the history and mechanics of homophobia, ${ }^{145}$ and also to any interests in cross-sex sexual privacy that individuals might have.

Same-sex privacy cases call forth legal subjects that are defined by an essentialized bodily modesty, one that is gendered female. They also imagine women as constitutively vulnerable to sexualized assault (again, from lower-class men-but not from women, or men higher up on the professionalism scale) and as unable to protect themselves. They produce legal subjects along a grid of "an idealized and compulsory heterosexuality." 146 They suggest that those higher up in class and professionalism hierarchies are less likely to abuse their positions. How exactly, and to what extent, these symbolic constructions effectively interpellate us are important questions that cannot be resolved here. My claim is simply that the norms involved create a world of gender meanings that have real and discriminatory effects, which we ought to resist.

\section{B. The Costs of Changing Gender Norms}

Ought we, then, simply refuse to shelter same-sex privacy norms from Title VII? The prison cases suggest tempering this impulse with another one that would attend to who bears the costs of changing gender norms. Consider the costs of changing the norm of same-sex privacy for one

143. If the "modesty" norm is gendered, as discussed above, then we should expect that norms about gender, not just norms about sexuality, are in opcration in scenes of same-sex privacy. Thus, we ought not replace the same-sex-as-private norm with a same-sexuality privacy norm (e.g., allowing gay men "sexual privacy" from other gay men) or a sex-of-object-choice privacy norm (e.g., allowing lesbians sexual privacy from other women).

144. Canedy v. Boardman, 16 F.3d 183, 185 n.1 (7th Cir. 1994).

145. It is clear that "same-sex" does not always mean "private," especially in environments that are fixated on the fantasmatic dangers that homosexuals pose to others. As Kendall Thomas has noted, the debate on gays in the military, occupied with anxiety about the penetrating samesex gaze, offers us a window into one such institution. Kendall Thomas, Shower/Closet, 20 ASSEMBLAGE 80, 80 (1993) ("From the media stories on heterosexuals in the armed forces who oppose President Clinton's proposal to lift the ban on the inclusion of 'avowed' homosexuals in their ranks, it would seem that straight male soldiers and sailors are haunted by the specter of the 'gay look."').

146. BUTLER, supra note 100, at 135. 
woman in a California prison: When male prison guards were assigned to conduct random, clothed body searches of female inmates and she was forced to undergo one against her will, she was so distressed that "her fingers had to be pried loose from the bars she had grabbed; she returned to her cell-block, vomited, and broke down." ${ }^{\prime 147}$ We could insist, of course, that her reaction was a kind of false consciousness, that she was misidentifying all men as a threat, or at least misidentifying this man as a threat. There is a way in which these things in fact might be true but is this the place to make that point? Would it be possible, in a context in which approximately eighty-five percent of women have been sexually or physically abused by men, ${ }^{148}$ to remake associations between gender and assault by ignoring them?

If Title VII is about transforming practices of gender, same-sex privacy cases suggest that we must not only decide which gender norms to change, but where and how to change them. But what does it mean to say that we ought to take the "costs" of changing gender norms into account?

The following account is necessarily schematic, but it attempts to outline an answer to this question. It suggests that there is a very limited category of costs with which we ought to be concerned, for the same reason that the BFOQ provision has been declared a narrow exception to Title VII: A broader scope would eviscerate the statute, and fatally undermine our ability to use antidiscrimination law to change discriminatory gender meanings. But our consideration should not end where we identify a cognizable cost. In almost every case, individuals and employers can avoid or substantially mitigate the costs in question. Indeed, where such costs are a concern, same-sex privacy BFOQs are likely to be an inadequate response to the concerns identified. This suggests that if we value employment equity (as Title VII suggests that we do) and are worried about the symbolic effects of the same-sex privacy BFOQ as it is currently constructed (as I have suggested that we ought to be), then rarely, if ever, will a same-sex privacy BFOQ be appropriate.

Because gender means so many things to us, changing gender norms is likely to occasion innumerable kinds of costs. Same-sex privacy cases suggest a few on which to focus: the discomfort associated with adapting to changed employment roles for women and men, the distress associated with challenges to our sense of gendered modesty and propriety, and the anxiety

147. Jordan v. Gardner, 986 F.2d 1521, 1534 (9th Cir. 1993) (Reinhardt, J., concurring). The Ninth Circuit held that the Eighth Amendment prevented male guards from performing body searches of women in this facility, stating that such searches involved the wanton infliction of pain, given the history of severe and endemic abuse experienced by women inmates in the facility. Id. at 1531 (majority opinion).

148. Id. at 1539 n. 14 (Reinhardt, J., concurring). 
associated with the sense of exposure to risk of sexual assault and harassment.

The first category of cost is in evidence in the labor and delivery room cases, where men are acceptable as doctors but not as nurses. It may be that asking women (and men) to accept men as nurses causes distress, but that distress itself simply cannot count for much when we are considering when and how to challenge discriminatory gender norms in the workplace. Where the cost in question is a fact of changing norms about gendered employment themselves, we ought no more accept it as applied to male nurses than female flight attendants.

The second category of costs, distress about gendered propriety and modesty, is probably in evidence in most-if not all-of the same-sex privacy cases. But here too we are faced with something that might be considered a transaction cost of antidiscrimination law. There is no way to articulate the costs of changing norms of same-sex modesty except as an expression of gender norms themselves - the "same-sex" aspect of this proves it. Once we decide that this norm is among those that Title VII properly seeks to change, then the costs of changing this regime-even where these costs are disproportionately borne by women-must be an inadequate reason to reject the attempt to transform it.

The last cost suggested by these cases is anxiety about sexual assault and harassment-and it is also the only one of the three that ought give us serious pause. We ought to distinguish between two forms of this cost: one associated with the fact that assault or harassment may occur in scenes of cross-sex bodily exposure and the other associated with the fear of assault, or in more extreme cases, the sense that cross-sex exposure itself is assaulting. Everson v. Michigan Department of Corrections can serve as an emblem of the first dilemma. ${ }^{149}$ Ought women bear the risk of sexual assault and harassment that history gives us reason to expect male guards will perpetrate more often than female guards? Surely not-but as we will discuss momentarily, there is no reason that they should have to.

The cost associated with the fear of assault in the prison, the labor and delivery room, the psychiatric ward, or the nursing home is a more difficult case. These anxieties too are likely to redound primarily to women, given the disproportionate burden that sexual assault and sexualized fear impose upon women. But in their more attenuated forms, these fears, like the regime of gendered modesty, are part of those gender norms that Title VII might rightfully seek to change, and thus, as with the costs of changing norms about modesty, cannot be considered grounds to abandon the project of changing subordinating gender meanings. However, the more extreme versions of this fear, such as are reflected in the above account from Jordan

149. See supra text accompanying note 146. 
v. Gardner, ${ }^{150}$ might be judged differently because they suggest that some individuals experience cross-sex exposure or touching itself as an assault. Without naturalizing the sense of gender-based trauma that such responses are said to arise out of, we nonetheless might agree that these costs are among those few we should take into account.

Taking note of such costs puts us in a double-bind, asking us to mediate between the discriminatory effects of a norm and the disproportionate burden placed on subordinated individuals that the attempt to transform the norm can have. But we are not required to choose between two kinds of discriminatory effect. There is a third way suggested by the third prong of the same-sex privacy test that most courts already use, which requires employers to show that there are no reasonable alternatives to a sex-based hiring policy. ${ }^{151}$ The foregoing suggests that courts ought to take this prong of the test much more seriously-not only to protect individuals from employment discrimination, but also to protect them from the things that we worry about when we talk about privacy. Thus, where the attempt to change gender norms occasions cognizable costs, we ought still attend to two things: alternatives that employers can adopt and the degree of mitigation that individuals themselves can exercise. As for the first, consider the one cost that it seems evident we want to avoid: increased incidence of sexual assault or harassment. It simply cannot be the case that the exclusion of one sex from particular job duties will be necessary or sufficient to prevent this risk, for two reasons: If there is risk of such misconduct, it will not only inhere in locations of bodily exposure, and it will not only inhere between sexes. As the Everson court noted, improper conduct occurs among all male staff members in the prisons in question, and "there appears to be no firm evidence that it is principally found among the [guards excluded from] the housing units." ${ }^{\text {,152 }}$ Furthermore, one of the premises of this Note is that sexual abuse and attraction do not simply occur between individuals of opposite sexes. Same-sex privacy norms can only successfully defend individuals from a particular kind of assault and harassment- - the kind that happens in scenes of genital exposure between different sexes. But consider the sexual profiling question from the perspective of male inmates. As a commentator recently noted:

[U]ndoubtedly because of long-standing stereotypes as to sexual conduct and aggression between men and women, the court cases, and the policies of prison authorities involve only situations where

150. 986 F.2d at 1534 .

151. See Jennings v. N.Y. State Office of Mental Health, 786 F. Supp. 376, 380-81 (S.D.N.Y. 1992), aff'd, 977 F.2d 731 (2d Cir. 1992); Fesel v. Masonic Home of Del., Inc., 447 F. Supp. 1346, 1351 (D. Del. 1978), aff'd mem., 591 F.2d 1334 (3d Cir. 1979).

152. Everson v. Mich. Dep't of Corr., 222 F. Supp. 2d 864, 872 n.12 (E.D. Mich. 2002). 
the safety of female inmates is allegedly threatened by the presence of male guards.... It is widely recognized that male inmates fear homosexual attacks and that body cavity searches often make inmates feel humiliated and vulnerable to a homosexual assault. ${ }^{153}$

Despite the fact that male guards appear to be responsible for a considerable proportion of sexual assaults against male inmates, ${ }^{154}$ there is no evidence, in case law or otherwise, that prison administrators are attempting to remove male guards from male housing units. ${ }^{155}$ At the same time, concern about the possibility of sexual abuse is increasingly cited as a reason that male guards must be removed from women's housing units. ${ }^{156}$

This is not to say that the best answer to sexual assaults in prison is to remove men from all guard positions-quite the opposite. It is to suggest that in almost every case, sex-neutral measures-for example, improving reporting systems and prosecutions-will likely be more effective at protecting inmates from sexual assault and harassment (as well as other kinds of abuse) than sexual profiling. ${ }^{157}$

Second, we ought to be less concerned about asking individuals to bear costs where they possess the resources to mitigate the costs themselves. Where individuals are in particularly vulnerable situations-for example, in residential care, psychiatric wards, or prisons-we ought to be more concerned about imposing costs upon them. Where individuals have extensive resources at their disposal to manage the costs of changing gender norms - either by avoiding them (e.g., by changing hospitals) or by ameliorating their effects (e.g., by asking for a chaperone) - we ought to be more comfortable with asking them to bear costs. Currently, we impose the

153. Ingram, supra note 78 , at 19 (citations omitted).

154. A recent study surveying nearly 10,000 staff and inmates in four Midwestern states found that about $20 \%$ of alleged assaults against male inmates were perpetrated by staff. Cindy Struckman-Johnson \& David Struckman-Johnson, Sexual Coercion Rates in Seven Midwesterm Prison Facilities for Men, 80 PRISON J. 379, 389 (2000); see also Cindy Struckman-Johnson et al., Sexual Coercion Reported by Men and Women in Prison, 33 J. SEX RES. 67, 71 (1996) (indicating that $18 \%$ of reported assaults against male inmates in one Midwestern facility were perpetrated by guards). It is possible to infer that male guards were more commonly the perpetrators in this latter study: Guard assaults were $18 \%$ of the total assaults, and women were the reported perpetrators in only $2 \%$ of these same assaults (women and men together were alleged perpetrators in another 5\%). Id.; see also Teresa A. Miller, Keeping the Government's Hands off Our Bodies: Mapping a Feminist Legal Theory Approach to Privacy in Cross-Gender Prison Searches, 4 BUFF. CRIM. L. REV, 861, 864 (2001) (noting that "judges tend to deploy privacy primarily as a means of protecting sexually vulnerable women-both guards and prisoners - from sexually aggressive men" and as a result fail to acknowledge "the sexual vulnerability of male prisoners").

155. See Ingram, supra note 78, at 12.

156. See, e.g., Everson, 222 F. Supp. 2d at 885, 897; see also David W. Chen, After Abuse Charges. Westchester Bars Male Guards from Women's Jail, N.Y. TIMES, Feb. 29, 2000, at B4 (reporting that Westchester County Executive Andrew J. Spano stated that he wished to protect female inmates from further sexual abuse and "announced today that male guards would be barred from working in the women's quarters of the county jail").

157. For a list of such possible measures, see Everson, $222 \mathrm{~F}$. Supp. $2 \mathrm{~d}$ at 871-72. 
highest costs on those with the fewest resources-women (and sometimes men) in prison. In truth, however, this trend ought to be inverted-so that those with the least resources to manage the impact of changing gender norms are no longer on the front lines while those with every resource are staunchly protected.

Finally, the above considerations suggest that we ought to attend to these costs only very rarely as a justification for defending same-sex privacy BFOQs, but regularly as a demonstration of the accommodations that will be necessary both to transform our notions of gender and to avoid disproportionately imposing the costs upon those with the fewest choices and resources. To acknowledge that there are costs associated with changing norms of gender does not mean that we ought to renounce the project of changing them; quite the contrary. It suggests first that we ought to minimize these costs where we are concerned about them, and only second - if at all-that we ought to authorize sex segregation to avoid them. There is, after all, also a cost associated with the status quo, as the previous Section has attempted to demonstrate.

\section{CONCLUSION}

Same-sex privacy cases cannot be justified as a simple act of statutory interpretation, nor as a logical extension of the privacy rights that sometimes attach to scenes of bodily exposure. They demonstrate, rather, that when courts interpret Title VII's BFOQ exception, they are arbitrating between the gender norms that antidiscrimination law ought to try to change and those norms that it ought to protect. By protecting same-sex privacy, courts, I have argued, are protecting norms about gender where these preferences are seen as deeply rooted in our culture and sense of self, or as a means of profiling risks of sexual assault or abuse.

The question, then, is not "ought Title VII protect norms about gender" (for the norm that gender is irrelevant is, of course, a norm too), but rather "which norms ought it protect?" I have suggested that we answer this by examining which norms have a materially and symbolically subordinating effect upon women. But we must also consider when and how to challenge such norms. I have contended that we should consider the potential effects of transforming gender norms upon the people we change them throughbut more often as a step toward finding non-sex-segregatory measures to mitigate potential harms than as a factor legitimating a BFOQ.

Applying these principles to same-sex privacy cases would allow courts to dispense with their awkward insistence that privacy rights require the granting of a same-sex privacy BFOQ. It would also encourage them to stop attributing these norms to biology or unchangeable notions of gender, 
and to admit instead that same-sex privacy is a socially and legally constituted practice of gender that the law can, and does, influence.

Instead of arguing from inalienable privacy or biological law, courts could concede that same-sex privacy is a gendered norm and a customer preference-and one that levies particular costs against women, while potentially sparing them others. They could then weigh openly the symbolic and material costs and benefits of changing gender norms in the context at issue. Thus, rather than deny that norms (and customer preferences) are at stake in cases like Backus, Fesel, or Everson, courts would admit that they are, but that we must consider what the costs of these norms are, and who ought to bear the cost of changing them.

This Note seeks more to provide a structure for same-sex privacy inquiries than to offer a series of conclusions about how they should be decided. We ought, I have suggested, be much more critical of the notion of "same-sex privacy" than courts have been to date, and attend to the kinds of subjects and harms that we are imagining when we talk about same-sex privacy. In the washroom cases and the labor and delivery room cases, where "modesty" or the avoidance of "tension" is all that can recommend the current regime, such an analysis will almost certainly militate against a BFOQ. Other cases suggest more caution-for example, where individuals have very little volition over the circumstances in which they participate in the changing of gender norms. Here, we ought to consider potential costs to both bodily and psychical integrity, but also recognize that regulating sex is not the same thing as regulating harm, anxiety, or the possibility of sexual abuse. In almost all cases, systemic rather than sex-segregationist approaches will likely provide better prophylaxis against abuse and anxiety about abuse because they will better serve to correct power imbalances that generate risk of abuse and that make abuse so injurious.

Finally, there is no way to decide, a priori, the answers to all of the questions proposed in this Note, but this is simply to say that there is a role for judgment and for courts as we know them. It is my hope, finally, that the preceding discussion has served at least to illuminate some of the unexamined meanings that same-sex privacy cases carry with them, and to explicate some of what it would mean to try to change them. 
***

Imaged with the Permission of Yale Law Journal 